\title{
BIOCHEMICAL DETECTION OF ALIEN DNA INCORPOR- ATED INTO WHEAT BY CHROMOSOME ENGINEERING
}

\author{
RICHARD FLAVELL, MICHAEL O'DELL, JÜRGEN RIMPAU† and DEREK SMITH \\ Department of Cytogenetics, Plant Breeding institute, Trumpington, \\ Cambridge CB2 2LQ
}

Received 3.x.77

\begin{abstract}
Summary
Wheat lines carrying homologous pairs of complete or telocentric rye chromosomes have been used to investigate the detection of rye chromosomes or chromosome fragments in a wheat genetic background, by nucleic acid hybridisation. Three different radioactive rye probes were used: (1) the most highly repeated DNA sequences made radioactive in vitro by " nick translation ", (2) the whole complement of repeated sequences radioactively labelled in vivo and (3) $25 \mathrm{~s}$ and $18 \mathrm{~s}$ ribosomal RNAs radioactively labelled in vivo. Radioactive highly repeated sequence DNA was hybridised to unlabelled DNAs from wheatrye chromosome addition lines immobilised on nitrocellulose filters. Ryespecific highly repeated sequences were detected in all the lines, illustrating that rye-specific highly repeated sequences reside on all chromosome arms. The effect of the size of the radioactive probe DNA was investigated by hybridising labelled rye repeated sequences to unlabelled DNAs from wheat-rye chromosome addition lines in solution. Short fragments round 300 nucleotides long detected rye-specific repeated sequences in all the unlabelled DNAs. Longer fragments, greater than 2000 nucleotides, were used to show that some of these rye-specific repeated sequences are in chromosomal regions which lack repeated sequences related to repeated sequences in wheat. The regions are probably considerably longer than 10,000 base pairs.

Saturating concentrations of $25 \mathrm{~s}$ and $18 \mathrm{~s}$ ribosomal RNAs were hybridised to DNAs from Holdfast wheat-King II rye chromosome addition lines bound to nitrocellulose filters. The results showed that chromosome $1 \mathrm{R}$ of King II possesses the major cluster of ribosomal RNA genes of rye. However with DNAs from Chinese Spring wheat-Imperial rye chromosome addition lines, those with rye chromosome $I R$ and chromosome $5 R$ had considerably more ribosomal RNA genes than Chinese Spring wheat.

Using labelled barley repeated sequences as probe DNA it was shown in wheat-barley DNA mixtures that it was possible to detect 0.05 per cent barley DNA, i.e. 5 parts in 10,000 , by incubating the DNAs to $\mathrm{C}_{0} \mathrm{t} 100$ at $70^{\circ} \mathrm{C}$ in $0 \cdot 12-\mathrm{M}$ phosphate buffer.

It is concluded that these sorts of experiments should be of considerable use for detecting the presence of alien chromosome segments in wheat and other plant species.
\end{abstract}

\section{INTRODUGTION}

Plant geneticists interested in crop improvement have long recognised the potential value of widening the available gene pool by incorporating alien genetic material into crop species. Such genetic material could specify new attributes not available in the particular crop species or could modify the expression of genes already in the crop species. Although attempts to introduce alien DNA into plants by many in vitro methods have, so far,

$\dagger$ Present address: Institut für Pflanzenbau und Pflanzenzuchtüng, Der Universität Göttingen, 34, Göttingen, West Germany. 
been inconclusive (see review by Lurquin, 1977), cytogeneticists exploiting the ability of common bread wheat, Triticum aestivum, to tolerate aneuploidy and to hybridise with other related species under special circumstances, have succeeded in incorporating alien chromosomes, or parts of alien chromosomes into wheat (see Riley and Kimber, 1966). The techniques that have been used can be aptly described as " chromosome engineering" (Sears, 1972).

Chromosome engineering with wheat and related species has led to the production of wheat lines possessing whole chromosomes, chromosome arms or segments from many species including rye (Riley and Chapman, 1958, 1960; Driscoll and Jensen, 1963; Driscoll and Sears, 1971), Aegilops umbellulata (Sears, 1956), Aegilops comosa (Riley, Chapman and Johnson, 1968) and Agropyron elongatum (Knott, 1961; Wienhues, 1966; Sears, 1972; Dvorak and Knott, 1974). The alien chromosomes are present as translocations, additions to or substitutions within the wheat chromosome complement. (For a review of wheat-alien chromosome lines see Driscoll, 1975). The construction and recognition of these lines have involved the use of cytological assays for the alien chromosomes (e.g. the extent of pairing with marker chromosomes during meiosis) together with, in many cases, genetic markers known to be present on the alien chromosomes. These assays for alien DNA are of limited use, especially when very small pieces of alien DNA have been incorporated.

Recently, the application of various metaphase chromosome banding techniques has enabled some alien chromosomes or chromosome segments to be recognised and thus their presence confirmed. Several laboratories have clearly demonstrated that rye chromosomes can be distinguished from wheat chromosomes in wheat-rye addition lines by their terminal heterochromatic regions that stain strongly with Giemsa stain (Sarma and Natarajan, 1973; Bennett, 1974; Verma and Rees, 1974; Darvey and Gustafson, 1975; Singh and Röbbelen, 1976). One example of the value of such staining methods has been illustrated by Bennett and Smith (1975). They demonstrated, using Giemsa staining, that certain commercial wheat varieties contain rye chromosomes or chromosome arms, a finding which agreed with conclusions drawn previously by cytogeneticists from meiotic chromosome pairing studies and the number of nucleolar organisers cytologically visible at metaphase (Mettin, Bluthner and Schlegel, 1973; Zeller, 1973).

The presence of alien chromosomes in genotypes derived from wheat has also been demonstrated biochemically; new isoenzymes have been found in tissue extracts that are not found in wheat (Bhatia and Smith, 1966; Barber, Driscoll and Vickery, 1968; Irani and Bhatia, 1972; MacDonald and Smith, 1972; Tang and Hart, 1975; Hart, McMillin and Sears, 1976). In these sort of tests the presence of alien genetic material is inferred from the occurrence of gene products characteristic of the chromosome donor species.

An alternative biochemical approach for detecting alien DNA is to use the techniques of DNA hybridisation. These have the advantages that they are sensitive and can detect DNA which does not code for easily detectable proteins. Such methods depend upon having a radioactively labelled probe which is homologous to the alien DNA but which does not show homology with the principal DNA. This paper is concerned with the 
application of such hybridisation techniques to detect alien DNA in wheat. Most of our studies have exploited wheat lines which also contain different pairs of homologous rye chromosomes. Three different radioactive probes have been used; two containing repeated sequences of rye and the third containing purified ribosomal RNA genes. This latter probe, though not rye specific, was chosen as an example of a specific sequence probe and also to determine which rye chromosome(s) carry ribosomal RNA genes. The detection of barley DNA in a large excess of wheat DNA using radioactive barley DNA as a probe is also described. This was attempted because of the effort now being put into the construction of wheat-barley chromosome addition lines (Islam, Shepherd and Sparrow, 1975).

\section{Materials AND methods}

(i) Plant genotypes

Two series of wheat-rye addition lines were used. One consisted of the wheat variety "Holdfast" and seven lines each possessing a different homologous pair of chromosomes or chromosome arms (telocentric chromosomes) from the rye variety " King II " (Riley and Chapman, 1958, 1960). The other series consisted of the wheat variety Chinese Spring and seven lines each possessing a different homologous pair of chromosomes from the rye variety "Imperial " (Driscoll and Sears, 1971). Seed of this series was kindly supplied by Dr E. R. Sears, University of Missouri, Columbia, Missouri, U.S.A. The homologous rye chromosomes in both sets of addition lines have, for simplicity, been given the numbers indicating their homoeologous groups within the Triticinae (see Koller and Zeller, 1976).

The telocentric chromosomes of King II are designated long or short ( $\mathrm{L}$ or $\mathrm{S}$ ) as appropriate where there is a marked size difference. The arms of chromosome $2 \mathrm{R}$, designated right and left, have been distinguished by their ability to confer resistance to Erysiphe graminis (Riley and Macer, 1966). The relationships of the King II and Imperial rye chromosomes to each other and to wheat chromosomes are discussed in Koller and Zeller (1976).

\section{(ii) Isolation of unlabelled and labelled DNAs}

Unlabelled DNAs were isolated from green leaf tissue of plants grown until approximately $25 \mathrm{~cm}$ high under continuous illumination. The details of the DNA purification have been described in detail previously (Smith and Flavell, 1974). In vivo tritium-labelled DNA was purified from about 3-day-old, dark grown seedlings, germinated in the presence of $\left\{\mathrm{Me}-{ }^{3} \mathrm{H}\right\}$ thymidine (specific activity-4l $\mathrm{Ci} / \mathrm{m} \mathrm{mol}$ ) also by procedures published previously (Smith and Flavell, 1974).

\section{(iii) $D \mathcal{N A}$ fragmentation and estimation of average fragment sizes}

Unlabelled DNA preparations were sheared by sonication in $0 \cdot 12-\mathrm{M}$ phosphate buffer. During sonication, the DNA solutions were kept cool by an ice bath. Weight average fragment lengths of denatured, sheared DNA preparations were determined by boundary velocity sedimentation in $0 \cdot 9-\mathrm{M} \mathrm{NaCl} 0 \cdot 1-\mathrm{M} \mathrm{NaOH}$ as described by Studier (1965) using an MSE 
"Centriscan" analytical ultracentrifuge. Tritium-labelled DNAs of different average fragment lengths were obtained by fractionating native DNA in 5 to 11 per cent $\mathrm{w} / \mathrm{w}$ linear sucrose gradients made in $0 \cdot 1-\mathrm{M} \mathrm{NaOH}$ after sedimentation for 19 hours at 24,000 r.p.m. at $20^{\circ} \mathrm{C}$. Each DNA fraction was neutralised, an equal volume of glycerol added and stored at $-20^{\circ} \mathrm{C}$. Weight average, single-stranded DNA fragment lengths in each gradient fraction were determined as described by Burgi and Hershey (1963) after sedimentation for 16 to 19 hours in identical gradients together with an unlabelled marker DNA whose molecular weight was known from analytical ultracentrifuge measurements.

\section{(iv) Renaturation of denatured $D \mathcal{N A}$ in solution and hydroxyapatite chromatography}

Unlabelled DNAs sheared to approximately 300 to 400 nucleotides, were mixed with the appropriate tritium labelled DNA in $0 \cdot 12-\mathrm{M}$ phosphate buffer such that the ratios of unlabelled : labelled DNA always exceeded $8000: 1$. After being denatured by incubation at $100^{\circ} \mathrm{C}$ for 5 minutes, the DNAs were incubated at $70^{\circ} \mathrm{C}$ or $60^{\circ} \mathrm{C}$ to a $\mathrm{C}_{0} \mathrm{t}$ of $100 . \quad\left(\mathrm{C}_{0} \mathrm{t}=\right.$ moles of nucleotides per litre $\times$ incubation time in seconds). The DNAs were then diluted with $0 \cdot 12$ - $\mathrm{M}$ phosphate buffer at $70^{\circ} \mathrm{C}$ or $60^{\circ} \mathrm{C}$, and chromatographed on hydroxyapatite in $0 \cdot 12-\mathrm{M}$ phosphate buffer. Denatured DNA was removed by washing at 68 or $58^{\circ} \mathrm{C}$ and renatured DNA by washing at $95^{\circ} \mathrm{C}$. Tritium-labelled DNA in the column eluates was estimated by precipitation with 5 per cent (final concentration) trichloroacetic acid in the presence of 100 to $150 \mu \mathrm{g}$ bovine serum albumin in the cold, collection on Whatman GF/B filters and counting in a scintillation mixture. The recovery of labelled DNA using this precipitation method did not vary with fragment size (Flavell and Smith, 1976).

\section{(v) Isolation of very rapid renaturing rye $D \mathcal{N} A$}

Rye DNA dissolved in 0.12-M phosphate buffer was sheared to an estimated average fragment length of about 800 nucleotide pairs. After melting at $100^{\circ} \mathrm{C}$ it was briefly incubated at $60^{\circ} \mathrm{C}$ and forced through a hydroxyapatite column equilibrated with $0 \cdot 12-\mathrm{M}$ phosphate buffer at $60^{\circ} \mathrm{C}$. The estimated incubation $\mathrm{C}_{0} \mathrm{t}$ value allowing for the time taken for the DNA to pass through the hydroxyapatite was 0.0125 . After washing away the denatured DNA fragments from the column with three, $3 \mathrm{ml}$ washes of $0 \cdot 12-\mathrm{M}$ phosphate buffer at $60^{\circ} \mathrm{C}$ the renatured fragments were eluted with $1 \mathrm{ml}$ washes of $0.5-\mathrm{M}$ phosphate buffer at $60^{\circ} \mathrm{C}$. The fractions containing renatured DNA were pooled, dialysed exhaustively against water, freeze dried and redissolved in a small volume of water. Approximately 10 per cent of the rye genome adhered to the hydroxyapatite and was eluted with $0 \cdot 5-\mathrm{m}$ phosphate buffer.

\section{(vi) "Nick translation" of very rapidly renaturing rye $D \mathcal{N} A$}

To radioactively label in vitro the very rapidly renaturing rye DNA, $1 \mu \mathrm{g}$ aliquots of the DNA were incubated at $15^{\circ} \mathrm{C}$ for 1 hour in a $0.1 \mathrm{ml}$ volume of $0.05-\mathrm{M}$ tris- $\mathrm{HCl}(p \mathrm{H} \mathrm{7.9}), 0.005-\mathrm{M} \mathrm{MgCl}_{2}, 0.01-\mathrm{M} 2$-mercaptoethanol and $50 \mu \mathrm{g} / \mathrm{ml}$ bovine serum albumin, containing $2 \times 10^{-4} \mu$ moles radioactive 
dATP, dGTP, dGTP and TTP (Radiochemical Centre, Amersham) and approximately 13 units of Escherichia coli DNA polymerase I (BoehringerMannheim) (Maniatis, Jeffrey and Kleid, 1975; MacGregor and Mizuno, 1976). The mixture was then extracted twice with phenol saturated with $2 \times \mathrm{SSC}$ and the aqueous layer loaded on to a Sephadex G-50 column, $35 \times 1 \mathrm{~cm}$. The DNA which was eluted with water was stored frozen. Specific activity of the DNA was approximately $5 \times 10^{6} \mathrm{cpm} / \mu \mathrm{g}$.

\section{(vii) DNA hybridisation on filters}

DNA in $0 \cdot 1 \times \mathrm{SSC}$ was denatured with an equal volume of $1-\mathrm{M} \mathrm{NaOH}$ and after 15 minutes 4 volumes of a $2: 1: 1$ mixture of $3-\mathrm{M} \mathrm{NaCl}, 1-\mathrm{M}$ tris- $\mathrm{HCl}(p \mathrm{H} 8.0)$ and $1-\mathrm{N} \mathrm{HCl}$ were added. The solution was passed through $10 \mathrm{~mm}$ diameter Millipore HAWP filters under gravity and the filters washed with $5 \mathrm{ml}$ of $6 \times \mathrm{SSC}$. ( $\mathrm{SSC}=0 \cdot 15-\mathrm{M}$ sodium chloride, $0.015-\mathrm{m}$ sodium citrate). Approximately $25 \mu \mathrm{g}$ of DNA was loaded on each filter. After drying in air the filters were stored at $-20^{\circ} \mathrm{C}$ until use. Immediately before hybridisation, the filters were heated at $80^{\circ} \mathrm{C}$ in vacuo for 2 hours. Two different hybridisation procedures were used:

(1) After a brief wash in $2 \times \mathrm{SSC}$ at room temperature the filters were incubated for 18 hours at $35^{\circ} \mathrm{C}$ ( 5 filters per ml of solution) in $2 \times \mathrm{SSC}$ 50 per cent formamide containing $40 \mu \mathrm{g} / \mathrm{ml}$ of denatured wheat DNA, sheared to an average fragment length of 400 nucleotides, and $0.37 \mu \mathrm{g} / \mathrm{ml}$ of denatured, nick translated, very rapidly reannealing rye DNA. The filters were then washed twice in $2 \times \mathrm{SSC} 50$ per cent formamide at $35^{\circ} \mathrm{C}$, washed twice in $2 \times \mathrm{SSC}$ at room temperature, dried and the bound tritium counted in a scintillation mixture. After counting, the scintillant mixture was removed from the filters by washing them in chloroform and then the DNA was hydrolysed from the filters by incubating at $100^{\circ} \mathrm{C}$ for 20 minutes in $1-\mathrm{N}-\mathrm{HCl}$. The DNA on each filter was estimated by assuming that the $\mathrm{OD}_{260}$ of $1 \mathrm{mg} / \mathrm{ml} \mathrm{DNA}$ hydrolysed in $1-\mathrm{N}-\mathrm{HCl} \equiv 27 \cdot 8$ (Brown and Weber, 1968). All results were corrected for the behaviour of filters lacking DNA. In every experiment five or six replicate filters of each genotype were included together with five of six filters loaded with Holdfast wheat DNA.

(2) After soaking in $2 \times$ SSC each filter was transferred to a glass microscope slide. $40 \mu \mathrm{l}$ of $2 \times$ SSC 50 per cent formamide containing $40 \mu \mathrm{g} / \mathrm{ml}$ of denatured, sheared wheat DNA and $0.07 \mu \mathrm{g} / \mathrm{ml}$ of denatured, nick translated very rapidly reannealing rye DNA were added to each filter. An acid-washed glass coverslip was placed over each filter and the glass slides sealed in boxes, the bottoms of which were covered with filter paper soaked in $2 \times$ SSC 50 per cent formamide. The sealed boxes were then incubated at $35^{\circ} \mathrm{C}$ for 18 hours. The filters were removed and then treated as described above in (1).

(viii) Preparation of ${ }^{3} H$-labelled ribosomal $R \mathcal{N A}$ and hybridisation to $D \mathcal{N} A$

Tritium-labelled ribosomal RNA was purified from wheat seedlings germinated in the presence of ${ }^{3} \mathrm{H}$ uridine, exactly as described previously (Mohan and Flavell, 1974). DNAs were denatured and loaded on to nitrocellulose filters as described in Materials and Methods (vii). Hybridisation was carried out in $6 \times \mathrm{SSC}$ containing $5 \mu \mathrm{g} / \mathrm{ml}$ of radioactive RNA at $70^{\circ} \mathrm{C}$ for 3 hours as described previously (Flavell and Smith, 1974; Mohan and Flavell, 1974). Five replicate filters loaded with DNA of each 
genotype were incubated together in each experiment along with five replicate filters containing only wheat DNA. The percentage of DNA bound to ribosomal RNA was calculated as described in Mohan and Flavell (1974).

\section{Results AND Discussion}

In designing experiments to detect alien DNA it is first necessary to consider what kinds of DNA are to be detected, their likely concentration and what DNA probes would be most suitable to detect these DNA sequences. To detect pieces of cereal chromosomes in other cereal species, we considered it highly likely that repeated sequences would be useful indicators of alien DNA for the following reasons: (1) repeated sequences account for approximately 75 per cent of cereal genomes (Flavell and Smith, 1976; Flavell, Rimpau and Smith, 1977; Smith and Flavell, 1977) and thus even quite small chromosome segments are likely to carry many repeated sequences; (2) repeated sequences renature more rapidly than single copy sequences and so would renature to a homologous probe DNA within acceptable experimental time scales even if they were in very low concentration in the recipient genome; (3) divergence of species invariably appears to correlate with the introduction of new families of repeated sequences (Flavell, Rimpau and Smith, 1977) and so it is reasonable to hope that many chromosome segments carry species-specific repeated sequences.

For attempts to detect rye DNA in wheat-rye chromosome addition line DNA the following calculations are relevant: the $1 C$ DNA content of rye is $9.5 \mathrm{pg}$ while that of wheat is $15.7 \mathrm{pg}$ (Bennett and Smith, 1976). Thus on assuming all seven rye chromosomes to be the same size (which they are not, Gustafson and Bennett, 1976), one rye chromosome as an addition to a full complement of wheat chromosomes would constitute about 8.5 per cent of the nuclear DNA and rye telocentric chromosomes would be about 2 to 5 per cent of the nuclear DNA. Approximately 75 per cent of the repeated sequences in rye are also present in wheat (Flavell, Rimpau and Smith, 1977), so the concentration of rye-specific repeated sequences to be detected in the background of wheat sequences is likely to constitute at most about 1 or 2 per cent of the nuclear DNA. This low concentration is another reason why it is technically simpler to search for alien repeated sequences rather than single copy sequences.

\section{(i) Detection of rye-specific repeated sequences in wheat-rye addition line DNAs bound to nitrocellulose filters}

The first experiments were designed to detect rye-specific repeated sequences in DNAs from wheat-rye addition lines bound to nitrocellulose filters. Hybridisation of DNA probes in solution to DNA immobilised on filters generally measures only repeated sequence homologies because only relatively low $\mathrm{C}_{0} \mathrm{t}$ values are reached. Therefore, we chose to use a radioactive rye probe consisting of only the most rapidly reannealing, i.e. the most highly repeated sequences. This DNA, labelled by " nick translation" was approximately 10 per cent of the rye genome and assumed to consist of $(a)$ sequences which renatured extremely rapidly by a single order reaction because reverse repeats were on the same fragment (Smith and 
Flavell, 1977); (b) the neighbouring sequences to these reverse repeats which would be on the same fragments; $(c)$ the very highly repeated sequences which renatured very rapidly by a second order reaction because of their high concentration and $(d)$ the neighbours to these very highly repeated sequences which would also be on the same fragments.

Two methods were used to hybridise this denatured radioactive rye probe DNA to denatured DNA of wheat-rye addition lines bound to nitrocellulose filters. The first was a batch method where 50 or more filters were incubated together in $2 \times \mathrm{SSC} 50$ per cent formamide for 18 hours at $35^{\circ} \mathrm{C}$, with $1 \mathrm{ml}$ of solution for every five filters. These incubation conditions were selected as being sufficiently stringent to ensure that the radioactive probe DNA would form stable duplexes only with filter-bound sequences which were very similar. To reduce the amount of labelled probe rye DNA binding to sequences also found in the wheat genome, a 100-fold excess of sheared unlabelled wheat DNA was mixed with the radioactive rye DNA in the incubation solution.

The amounts of rye probe DNA that hybridised with the filter-bound DNAs from all seven different lines which carry whole rye chromosomes in addition to the full wheat complement and from 11 different lines which carry short or long arms or rye chromosomes are shown in table 1. The results are expressed relative to the amounts of radioactive rye DNA hybridised to bound, unlabelled, Holdfast wheat DNA. In every case where rye DNA was known to be present, the amount of radioactive rye probe DNA was significantly greater than to Holdfast wheat DNA. These results clearly illustrate the detection of rye DNA and also indicate that highly repeated rye-specific sequences are present on all rye chromosomes and chromosome arms tested.

\section{TABLE 1}

Hybridisation of very rapidly reannealing DNA of rye to DNA from wheat-rye chromosome addition lines on filters incubated together

$\begin{array}{cccc}\begin{array}{c}\text { King II rye chromosome } \\ \text { added to Holdfast wheat }\end{array} & \begin{array}{c}\text { Level of } \\ \text { hybridisation }\end{array} & \begin{array}{c}\text { King II rye chromosome } \\ \text { added to Holdfast wheat }\end{array} & \begin{array}{c}\text { Level of } \\ \text { hybridisation }\end{array} \\ - & 100 & 5 & 170 \dagger \\ 1 & 223 \dagger & 5 \mathrm{~L} & 143 \dagger \\ 1^{\mathrm{L}} & 180 & 5^{\mathrm{s}} & 157 \\ 2^{\text {right }} & 144 \dagger & 6 & 201 \dagger \\ 2^{\text {left }} & 213 \dagger & 6 \mathrm{6} & 146 \dagger \\ 3^{\mathrm{s}} & 200 \dagger & 6^{\mathrm{s}} & 173 \\ 4^{\mathrm{s}} & 192 \dagger & 7 & 187 \dagger \\ 4^{\mathrm{L}} & 137 & 7 \mathrm{~L} & 183 \\ 4^{\mathrm{s}} & 145 \dagger & & \\ & 188 \dagger & & \end{array}$

a All values are means of five replicates of amount of labelled rye DNA hybridised per $\mu \mathrm{g}$ of filter-bound DNA expressed relative to the mean amount of labelled rye DNA hybridised per $\mu \mathrm{g}$ of filter-bound Holdfast DNA. All hybridisation levels to addition line DNAs are significantly greater than to Holdfast DNA at the I per cent level of probability except those marked $\dagger$ which are significantly greater at the $0 \cdot 1$ per cent level of probability. 
In the second method, filters containing unlabelled DNA were incubated one at a time with radioactive rye probe DNA to conserve radioactive DNA. The results of these hybridisations are shown in table 2. Again, in every case where a rye chromosome was known to be present, the amount of radioactive DNA binding to the filters was greater. This method is therefore also a convenient one and conserves radioactive probe DNA. The levels of hybridisation of labelled rye DNA to DNAs from telocentric addition lines were, in some cases, greater than to the DNAs from the related complete chromosome addition lines (see tables 1 and 2). The reasons for this have not been investigated. However it is noteworthy that the addition chromosome $2 \mathrm{R}$ which shows low hybridisation (tables 1 and 2 ) has lost a heterochromatic telomere that is present on the homologous telocentric chromosome (Singh and Röbbelen, 1976).

\section{TABLE 2}

Hybridisation of very rapidly reannealing rye DNA to DNA from wheat-rye chromosome addition lines on filters incubated separately, under coverslips

King II rye chromosome added to Holdfast wheat

-
1
2
2
3
4
$4 \mathrm{~s}$
5
$5 \mathrm{~s}$
6
$6 \mathrm{~s}$
7

Level of hybridisation ${ }^{\mathrm{a}}$

100

$153 \dagger$

121

173

172

154

249

$172 \dagger$

166

158

$184 \uparrow$

172

a All values are means of five replicates of amount of labelled rye DNA hybridised per $\mu \mathrm{g}$ of filter-bound DNA expressed relative to the mean amount hybridised per $\mu \mathrm{g}$ of filterbound Holdfast DNA. All hybridisation levels to addition line DNAs are significantly greater than to Holdfast DNA at the 5 per cent level of probability except those marked $\uparrow$ which are significantly greater at the 1 per cent level of probability.

(ii) Detection of rye-specific sequences in wheat-rye addition line DNAs in solution

Incubation of DNAs at high concentration in solution enables sequences in lower concentration in the genome to renature. Essentially all sheared fragments of cereal DNAs containing repeated sequences renature by $\mathrm{C}_{0} \mathrm{t}$ 50 (Flavell and Smith, 1976; Smith and Flavell, 1975, 1977). Renaturation of repeated sequences in cereals starts around $\mathrm{C}_{0} \mathrm{t} 0.01$. Therefore, for example, repeated sequences in alien DNA diluted 1000-fold by the DNA of the recipient genome should be detectable by incubation to $\mathrm{C}_{0} \mathrm{t} 50$.

To detect rye DNA in wheat-rye addition line DNA in solution $(0 \cdot 12-\mathrm{M}$ phosphate buffer), DNAs from the wheat-rye addition lines and also wheat and rye were sheared to average fragment lengths of 300-400 nucleotide pairs and mixed with tritium-labelled probe DNA. The probe was whole 
rye genome DNA of different fragment sizes ranging from 200 to 4000 nucleotides. This enabled us to investigate the effect of fragment size on renaturation and to study the distribution of rye-specific repeated sequences in the rye chromosomes (Smith and Flavell, 1977). The unlabelled DNA was in a greater than 8000 -fold excess over the labelled probe DNA so that the renaturation of labelled DNA fragments to other labelled DNA fragments would be essentially eliminated. After denaturation, the DNA mixtures were incubated at $70^{\circ} \mathrm{C}$ in $0.12-\mathrm{M}$ phosphate buffer to a $\mathrm{C}_{0} \mathrm{t}$ value of 100. The DNAs were then fractionated by hydroxyapatite chromatography and the proportion of the labelled rye DNA that was in the fraction containing double-stranded regions was determined as described in Materials and Methods. The results for three different unlabelled DNAs are shown in fig. 1.

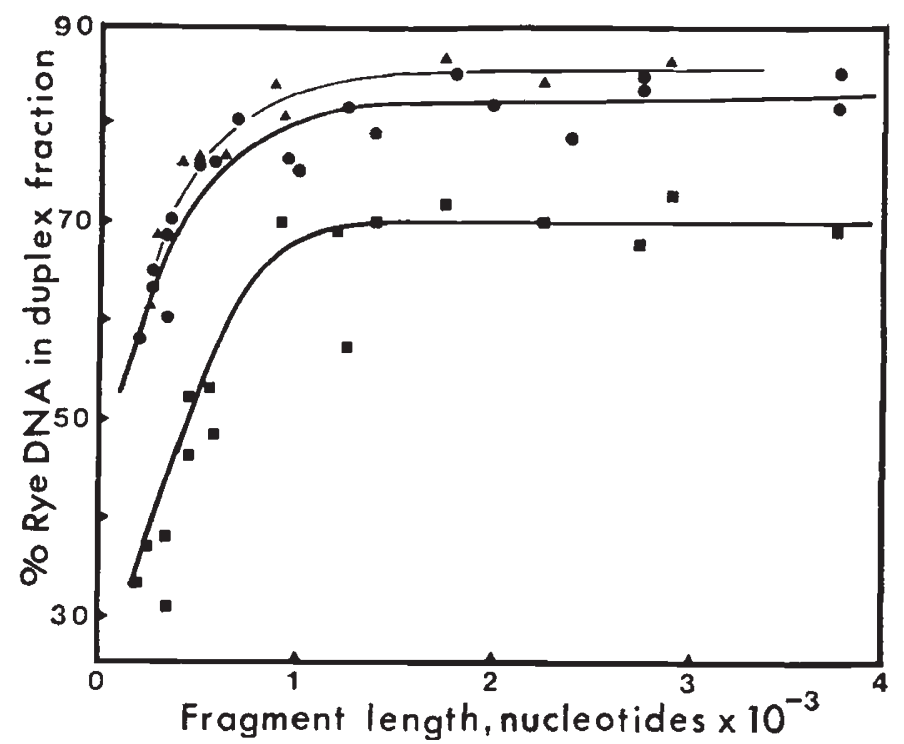

Fig. 1.-Hybridisation of rye DNA fragments of differing length to DNAs from wheat, rye and wheat + rye chromosome $4 \mathrm{R}$. Radioactive rye DNA fragments of different lengths were incubated to $\mathrm{C}_{0} \mathrm{t} 100$ at $70^{\circ} \mathrm{C}$ with $>8000$-fold excesses of unlabelled DNA from wheat ( $\mathbf{D})$, rye $(\mathbf{\Delta})$ and wheat + rye chromosome $4 \mathrm{R}(\mathbf{O})$. The proportions of renatured rye DNA were then determined by hydroxyapatite chromatography. These were corrected for the proportions of labelled DNA which renatures by intrastrand hybridisation and not by hybridisation with an unlabelled DNA fragment. The correction factor was as described by Flavell and Smith (1976) :

$$
\frac{\% \text { DNA in duplex - \% DNA in intrastrand duplex }}{100-\% \text { DNA in intrastrand duplex }}
$$

The values of the percentage DNA in intrastrand duplex fraction for each rye DNA fragment size were taken from Smith and Flavell (1977).

There are several important features of the curves in fig. 1. The proportion of labelled probe DNA in the hydroxyapatite duplex fraction is very dependent upon fragment length with fragments less than about 1000 nucleotides long. The actual proportion of labelled rye DNA that forms a duplex with the unlabelled DNA under the incubation conditions can 
be estimated from extrapolation to the ordinate (Smith, Rimpau and Flavell, 1976). Thus approximately 25 to 30 per cent of the rye genome renatures with unlabelled wheat DNA and a further 25 per cent when rye DNA is also present. This confirms that the rye-specific repeated sequences can be detected under these conditions.

The sharp rise in the proportion of labelled rye DNA in the hydroxyapatite duplex fraction when longer fragments were used is principally due to other sequences, unable to hybridise to the unlabelled DNA, being on the same fragments as sequences which do hybridise (Smith, Rimpau and Flavell, 1976). Those sequences which do not hybridise in the homologous combination (labelled rye DNA + unlabelled rye DNA) could be nonrepeated or few copy sequences and/or repeated sequences which have diverged sufficiently far from other members of their families that they cannot form stable duplexes at $70^{\circ} \mathrm{C}$ in $0 \cdot 18-\mathrm{M} \mathrm{Na}^{+}$. In the heterologous situation (labelled rye DNA + unlabelled wheat DNA) they could also be rye species-specific repeated sequences. The presence of different kinds of sequences on the same fragments implies different sequences are interspersed with one another in the rye genome (Rimpau, Smith and Flavell, 1977). Since the proportion of the labelled rye DNA in the hydroxyapatite duplex fraction did not increase when the fragment size exceeded 1200 nucleotides, the lengths of the sequences in the rye genome interspersed between those repeated sequences able to renature under the hybridisation conditions are less than 1200 base pairs (Smith and Flavell, 1977).

The proportion of the labelled rye DNA included in the hydroxyapatite duplex fraction with fragment lengths above 1200 nucleotides was approximately 70 per cent when hybridised with unlabelled wheat DNA, 85 per cent when hybridised with unlabelled rye DNA and 82 per cent when hybridised with unlabelled wheat + rye chromosome 4R DNA. The curves with unlabelled wheat and rye DNAs imply that the 25 to 30 per cent rye repeated sequences able to hybridise to wheat DNA are concentrated in 70 per cent of the rye genome and the 50 per cent rye sequences able to hybridise to rye DNA are concentrated in 85 per cent of the rye genome. Thus, there is approximately 15 per cent of the rye genome in which ryespecific repeated sequences are clustered. These regions of the rye chromosomes, which are probably considerably longer than 10,000 base pairs, lack repeated sequences closely related to the repeated sequences in wheat. The similarity of the curves with unlabelled rye DNA and unlabelled wheat + rye chromosome 4R DNA implies that a substantial proportion of the kinds of rye-specific repeated sequences are present on rye chromosome $4 R$. It is possible that all the kinds of rye-specific repeated sequences are present in chromosome $4 \mathrm{R}$ but failed to renature because they are in a much lower concentration in DNA isolated from addition line plants than in DNA isolated from rye plants. Incubation to larger $\mathrm{C}_{0} \mathrm{t}$ values would be necessary to investigate this further.

From these results, it can therefore be concluded that using short labelled probe fragments the presence of rye-specific repeated sequences can be detected. Using long probe fragments it is possible to detect the rye-specific repeated sequences localised in long regions in which all the repeated sequences are rye-specific.

To test for rye-specific repeated sequences in all seven different wheatrye addition lines based upon Holdfast wheat, sheared denatured unlabelled 
DNAs from wheat and each addition line were incubated with a large excess of denatured sheared labelled rye DNA to $\mathrm{C}_{0} \mathrm{t} 100$ at $60^{\circ} \mathrm{C}$ (not $70^{\circ} \mathrm{C}$ as in other experiments) in $0 \cdot 12-\mathrm{M}$ phosphate buffer. The proportions of labelled DNA in the hydroxyapatite duplex fractions were determined. The results, shown in table 3 , illustrate that a significantly higher proportion of labelled rye DNA hybridised to unlabelled DNA when rye DNA was known to be present in the unlabelled DNA.

TABLE 3

Hybridisation of labelled rye DNA fragments about 300 nucleotides long to unlabelled DNAs from wheat-rye chromosome addition lines

King II rye chromosome added to Holdfast wheat

$\begin{array}{cc}- & 64 \cdot 9 \pm 1 \cdot 45^{2} \\ 1 & 73 \cdot 8 \pm 1 \cdot 83 \\ 2 & 71 \cdot 9 \pm 0.75 \\ 3 & 75 \cdot 2 \pm 0 \cdot 79 \\ 4 & 72 \cdot 2 \pm 0.23 \\ 5 & 72 \cdot 7 \pm 0.90 \\ 6 & 73 \cdot 9 \pm 0.51 \\ 7 & 68 \cdot 9 \pm 4 \cdot 20 \\ \text { All }(1 \text { to } 7)^{\mathbf{b}} & 75 \cdot 4 \pm 1.17\end{array}$

a Significantly lower than all other results at 5 per cent level of significance. Hybridisation of labelled rye to unlabelled wheat, wheat-rye chromosome addition and rye DNAs was carried out to $\mathrm{C}_{0} \mathrm{t} 100$ at $60^{\circ} \mathrm{C}$ in $0 \cdot 12$ - $\mathrm{M}$ phosphate buffer.

b This genotype which contained all the King II chromosomes as well as the Holdfast wheat chromosomes is the octaploid triticale from Holdfast $\times$ King II.

To test for the presence of the rye-specific repeated sequences clustered in chromosomal regions where all the repeated sequences are rye-specific, labelled denatured rye DNA fragments between 1200 and 4000 nucleotides long were incubated at $70^{\circ} \mathrm{C}$ in $0 \cdot 12-\mathrm{M}$ phosphate buffer with a large excess of denatured sheared unlabelled DNAs from wheat, rye and 17 different wheat-rye addition lines. The proportions of the labelled rye DNA in the hydroxyapatite duplex fractions are shown in table 4. Again, the proportions of labelled rye probe DNA were higher when unlabelled rye DNA was known to be present. These results confirm that each of the seven rye chromosomes possesses rye-specific repeated sequences which are similar to or identical with those concentrated in regions, probably considerably longer than 10,000 base pairs, which contain no repeated sequences homologous to repeated sequences in wheat.

\section{(iii) Detection of barley $D \mathcal{N} A$ in wheat-barley $D \mathcal{N} A$ mixtures}

Barley is more distantly related to wheat than is rye. Barley and wheat DNAs have fewer repeated sequences in common than rye and wheat DNAs (Smith and Flavell, 1974; Flavell, Rimpau and Smith, 1977). Therefore, the detection of barley DNA in a large excess of wheat DNA should be easier than the detection of rye DNA.

Labelled barley DNA fragments between 1100 and 3600 nucleotides long were incubated to $\mathrm{C}_{0} \mathrm{t} 100$ in $0 \cdot 12-\mathrm{M}$ phosphate buffer at $70^{\circ} \mathrm{C}$ with a 9000 fold excess of unlabelled wheat DNA sheared to about 300 nucleotides. 
TABLE 4

Hybridisation of labelled rye DNA fragments greater than 1200 nucleotides long to DNAs from wheat-rye chromosome addition lines King II rye chromosome
added to Holdfast wheat

$\begin{array}{ll}- & 62 \\ 1^{L} & 72 \\ 2 & 77 \\ 2^{\text {right }} & 78 \\ 2^{\text {Ieft }} & 70 \\ 3 & 73 \\ 3^{\mathrm{s}} & 72 \\ 4 & 70 \\ 4^{\mathrm{L}} & 74 \\ 4^{\mathrm{s}} & 74\end{array}$

King II rye chromosome added to Holdfast wheat

$$
\% \text { of rye DNA in }
$$
duplex fraction ${ }^{\mathrm{a}}$

$\begin{array}{cc}5 & 72 \\ 5^{\mathrm{L}} & 74 \\ 5^{\mathrm{s}} & 77 \\ 6 & 73 \\ 6^{\mathrm{L}} & 75 \\ 6^{\mathrm{s}} & 69 \\ 7 & 71 \\ 7 \mathrm{~L} & 76 \\ \text { All }(1 \text { to } 7)^{\mathrm{b}} & 80\end{array}$

a Each value is a mean of three. The three values were from hybridisations involving rye DNA fragments of three different lengths between 1200 and 4000 nucleotides. Hybridisation was carried out to $\mathrm{C}_{0} \mathrm{t} 100$ at $70^{\circ} \mathrm{C}$ in 0.12 - $\mathrm{M}$ phosphate buffer.

b This genotype which contained all the King II and Holdfast wheat chromosomes is the octaploid triticale from Holdfast $\times$ King II.

The proportion of labelled barley DNA in the hydroxyapatite duplex fraction was approximately 32 per cent. When unlabelled barley DNA was mixed with the unlabelled wheat DNA to concentrations of 2 per cent and 6 per cent, the proportion of labelled barley probe DNA that was in the hydroxyapatite fraction after incubation at $70^{\circ} \mathrm{C}$ to $\mathrm{C}_{0} \mathrm{t} 100$ was around 60 per cent (fig. 2). It did not vary substantially with labelled DNA

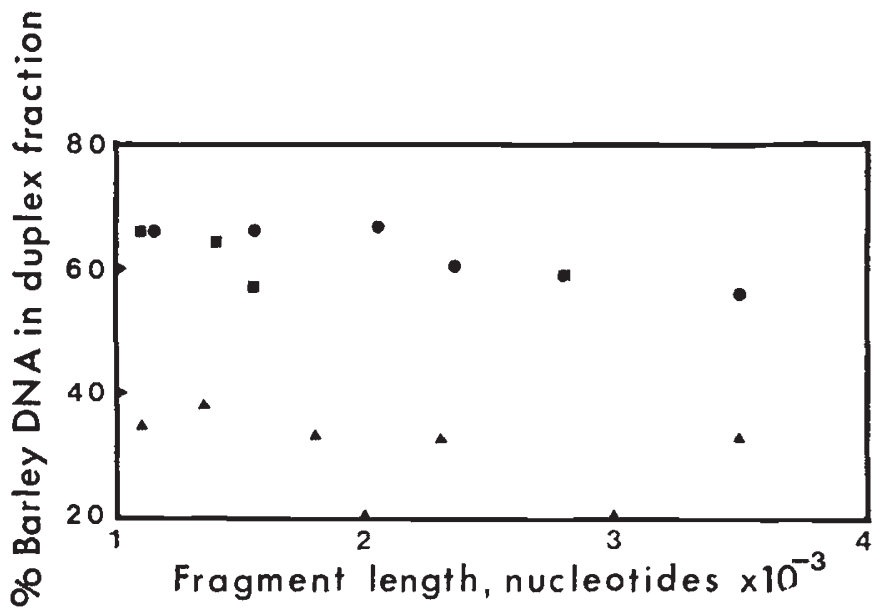

FIG. 2.-Hybridisation of labelled barley DNA fragments to wheat DNA and mixtures of wheat and barley DNAs. Radioactive barley DNA fragments of different lengths were incubated to $\mathrm{C}_{0} \mathrm{t} 100$ at $70^{\circ} \mathrm{C}$ with $>8000$-fold excesses of unlabelled wheat ( $\mathbf{\Delta}$ ), wheat containing 2 per cent of barley ( $\square$ ) and wheat containing 6 per cent of barley DNA ( ). The proportions of renatured labelled barley DNA were then determined by hydroxyapatite chromatography and corrected for the barley DNA which renatures by intrastrand reassociation (see legend to fig. 1). 
fragment size between 1100 and 3600 nucleotides. This considerable increase demonstrates the effectiveness of this method for detecting small amounts of barley DNA that would be equivalent to less than one chromosome arm in each haploid set of wheat chromosomes.

To gain an estimate of the amount of barley DNA that could be detected in a wheat nucleus, barley DNA was added to wheat DNA to be $5,1,0.5$, $0.1,0.05,0.01$ and 0 per cent of the total DNA. Labelled barley DNA fragments 2000 to 3000 nucleotides long were incubated with the denatured, sheared unlabelled DNA mixtures to $\mathrm{C}_{0} \mathrm{t} 100$ at $70^{\circ} \mathrm{C}$ in $0 \cdot 12-\mathrm{M}$ phosphate buffer and the proportions of labelled barley DNA in the hydroxyapatite duplex fraction were determined. The results, shown in fig. 3, illustrate that 0.05 per cent barley DNA in a wheat barley DNA mixture, i.e. five parts in 10,000 could be detected by incubating to $\mathrm{C}_{0} \mathrm{t} 100$. Although the $\mathrm{C}_{0} \mathrm{t}$ value for total unlabelled DNA in this experiment in fig. 3 was 100 ,

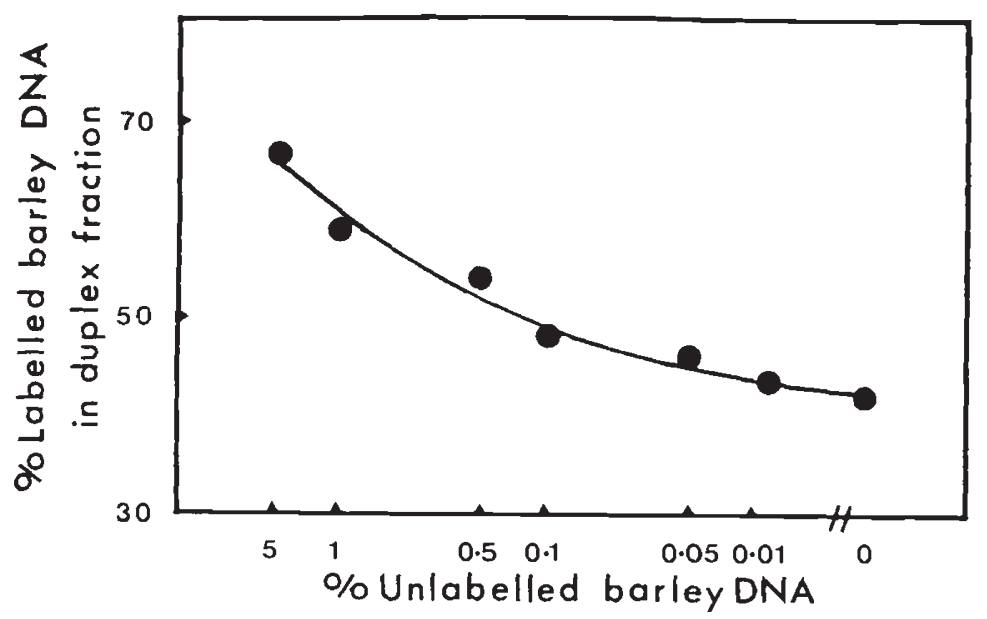

FIG. 3.-Detection of barley DNA in wheat-barley DNA mixtures. Labelled barley DNA fragments, of mean length between 2000 and 3000 nucleotides were incubated at $70^{\circ} \mathrm{C}$ to $\mathrm{C}_{0} \mathrm{t} 100$ with a 9000 -fold excess of unlabelled wheat DNA mixed with barley DNA in $0 \cdot 12-\mathrm{M}$ phosphate buffer. The proportions of barley DNA in the unlabelled DNA mixture varied from 0 to 5 per cent. The proportion of labelled barley DNA in the hydroxyapatite duplex fraction was determined, corrected for intrastrand reassociated DNA (see fig. 1) and is plotted against the percentage of unlabelled barley DNA in the unlabelled DNA mixture. For ease of representation this is plotted on a log scale. The results are mean values of two replicate experiments.

the $\mathrm{C}_{0} \mathrm{t}$ for the unlabelled barley DNA was $0.0005 \times 100=0.05$. Only a small proportion of barley repeated sequences reanneal at this $\mathrm{C}_{0}$ t value (unpublished results), so it would be expected that barley sequences would be only just detectable in a $100: 0.05$ wheat-barley DNA mixture incubated to $\mathrm{C}_{0} \mathrm{t} 100$. Undoubtedly smaller amounts could be detected if incubations were continued for a longer time.

\section{(iv) Hybridisation of ribosomal $R \mathcal{N} A$ to $D \mathcal{N} A$ s from wheat-rye addition lines}

As an example of the use of a specific sequence probe, we chose highly purified ribosomal RNAs. A mixture of tritium labelled $18 \mathrm{~s}$ and $25 \mathrm{~s}$ ribo- 
somal RNAs was purified from seedlings germinated in the presence of ${ }^{3} \mathrm{H}$ uridine. Filters loaded with DNA from two sets of wheat-rye addition lines were incubated in the presence of saturating amounts of the RNAs for 3 hours in $6 \times \mathrm{SSC}$ at $70^{\circ} \mathrm{G}$. The proportion of DNA hybridising to RNA on each filter was determined and the results are shown in table 5 together with the estimated number of genes specifying 18 s and 25s ribosomal RNAs derived from these proportions. Although considerable hybridisation of ribosomal RNA to DNA occurred with all DNAs, since all lines carry ribosomal RNA genes, there was a 30 per cent larger hybridisation to DNA from the line in which chromosome $1 \mathrm{R}$ of King II rye is present in addition to the Holdfast wheat chromosome complement. A 60 per cent increase in hybridisation was also found with DNA from the line in which chromosome $1 \mathrm{R}$ of Imperial rye is present in addition to the Chinese Spring wheat

\section{TABLE 5}

Hybridisation of ribosomal $R \mathcal{N} A$ to $D \mathcal{N} A$ s from wheat-rye chromosome addition lines

\begin{tabular}{|c|c|c|c|c|c|}
\hline $\begin{array}{l}\text { King II rye chromosome } \\
\text { added to Holdfast wheat }\end{array}$ & $\stackrel{\%}{\text { hybridisation }}$ & $\begin{array}{l}\text { No. of } \\
\text { rRNA }^{b} \\
\text { genes }\end{array}$ & $\begin{array}{c}\text { Imperial rye } \\
\text { chromosome added } \\
\text { to Chinese Spring } \\
\text { wheat }\end{array}$ & $\frac{\%}{\text { hybridisation }^{2}}$ & $\begin{array}{l}\text { No. of } \\
\text { rRNA }^{\mathrm{b}} \\
\text { genes }\end{array}$ \\
\hline- & $0 \cdot 066$ & 7040 & - & 0.090 & 9600 \\
\hline 1 & $0 \cdot 080$ & 9160 & 1 & $0 \cdot 135$ & 15550 \\
\hline 2 & $0 \cdot 063$ & 7242 & 2 & $0 \cdot 086$ & 9900 \\
\hline 3 & $0 \cdot 061$ & 7030 & 3 & 0.071 & 8179 \\
\hline 4 & 0.067 & 7668 & 4 & $0 \cdot 087$ & 10020 \\
\hline 5 & $0 \cdot 058$ & 6710 & 5 & $0 \cdot 120$ & 13800 \\
\hline 6 & $0 \cdot 061$ & 7030 & 6 & $0 \cdot 077$ & 8870 \\
\hline 7 & $0 \cdot 060$ & 6920 & 7 & $0 \cdot 081$ & 9331 \\
\hline
\end{tabular}

a The percentages are the mean values for five replicate filters. Only one preparation of DNA was used for each set of filters.

b The number of genes was determined from the hybridisation percentages assuming that the $1 G$ DNA content of wheat is approximately $1.0 \times 10^{13}$ daltons, the molecular weight of the ribosomal RNAs is $2 \cdot 0 \times 10^{6}$ daltons and each rye chromosome contains 8.5 per cent of the DNA in hexaploid wheat.

chromosome complement. These results imply that several thousand ribosomal RNA genes reside on chromosome $\mathrm{IR}$ of rye. This is consistent with cytological observations of a nucleolar organiser constriction visible at metaphase on this chromosome (Darvey and Gustafson, 1975) and the ribosomal genes being clustered at nucleolar organisers (Birnstiel, Chipchase and Spiers, 1971). The presence of 2000 additional ribosomal RNA genes in Holdfast-King II chromosome $\mathrm{IR}$ addition line and 6000 additional ribosomal RNA genes in the Chinese Spring-Imperial chromosome $1 \mathrm{R}$ addition line, implies that homologous chromosomes in different rye varieties carry different numbers of ribosomal RNA genes. This situation has been described previously (Flavell and Smith, 1974; Flavell and Rimpau, 1975). However, the possibility that this variation is due to changes in the number of wheat ribosomal RNA genes during the construction and maintenance of the stocks cannot be eliminated.

Considerably higher hybridisation levels of ribosomal RNA to DNA also occurred with DNA from Imperial rye chromosome 5R. Since there was no evidence for ribosomal RNA genes on chromosome $5 \mathrm{R}$ of King II 
rye, and no nucleolar organiser constriction being visible on this chromosome, these results should be interpreted with caution. It is possible that there may have been a change in the ribosomal RNA gene number in the wheat chromosomes during the maintenance of this particular addition line (see Flavell and Smith, 1974).

\section{Conclusions}

Using the techniques described in this paper there was no difficulty in detecting rye-specific repeated sequence DNA in individual rye whole chromosomes or telocentric chromosomes present in a complete complement of wheat chromosomal DNA. Many variations and combinations of these methods are obviously possible.

The extent to which these probes, viz. the full repeated sequence complement and the most highly repeated sequences of rye, will be successful in detecting small pieces of rye chromosomes incorporated into wheat depends upon the distribution of the rye-specific repeated sequences in the rye chromosomes. Studies to be presented elsewhere (Rimpau, Smith and Flavell, in preparation) have shown that rye-specific repeated sequences are concentrated in regions which occupy in total 34 per cent of the rye genome. The results in this paper show that some of these regions are present in each of the rye chromosome arms (tables 1, 2, 3 and 4). The length of each of the regions and their distribution along the chromosomes is not known but there is a good chance that the regions are sufficiently dispersed over the chromosomes that they will serve as markers for even very small rye chromosomal fragments. The barley-specific repeated sequences in barley chromosomes are concentrated in regions which occupy 44 per cent of the genome and oats-specific repeated sequences are concentrated in regions which occupy 66 per cent of the genome (Rimpau, Smith and Flavell, in preparation). These results suggest that repeated sequence DNA probes should be generally very useful for detecting the incorporation of chromosome segments from these related cereal species into wheat. Oats fragments in wheat would presumably be the easiest to detect, followed by barley and then rye, based upon the proportions of speciesspecific repeated sequences in these genomes. Different Aegilops and Triticum species DNAs would be expected to be more difficult to distinguish but preliminary results suggest that even these DNAs can be distinguished by these approaches.

The use of radioactive probes containing a large number, if not all the families of repeated sequences of the genome, are of little use in determining which chromosome, chromosome arm or chromosome fragment has been incorporated into the nucleus of another species. Probes containing one or a few sequences, such as the ribosomal RNA probe are necessary. Other probes similar to 25 s and 18 s ribosomal RNAs, such 5 s and 4 s RNAs can be prepared relatively easily, and will also probably serve as useful chromosome markers. The cloning of small cereal DNA fragments in bacterial plasmids and isolation of "satellite" DNAs should also produce probes with a high probability of hybridising to specific regions of specific chromosomes. It should be possible to identify these regions by in situ hybridisation of the radioactive DNA probes to cytological squashes of metaphase chromosomes (Pardue and Gall, 1975). 
If a large number of chromosome-specific DNA probes can be developed, then characterisation of alien cereal chromosome segments introduced into wheat by the well-established techniques of chromosome engineering in these species (Riley and Kimber, 1966; Sears, 1972) should be considerably easier.

\section{References}

BARBER, H. N., DRISGOLL, C. J., AND VICKERY, R. S. 1968. Enzymic markers for wheat and rye chromosomes. Proc. 3rd Int. Wheat Genet. Symp., 116.

BENNETT, M. D. 1974. Meiotic, gametophytic and early endosperm development in Triticale. In R. McIntyre and M. Campbell (eds), Triticale; Proc. Int. Symp. El Batan, Mexico.

BENNETT, M. D., AND SMITH, J. B. 1975. Confirmation of the identification of the rye chromosomes in $1 \mathrm{~B} / \mathrm{IR}$ wheat-rye chromosome substitution and translocation lines. Can. $\mathcal{F}$. Genet. Cytol., 17, 117-120.

BENNETT, M. D., AND SMTTH, J. B. 1976. Nuclear DNA amounts in angiosperms. Phil. trans of Royal Soc. (Lond.), 274, 227-274.

Bhatia, C. R., AND smtr, H. H. 1966. Variation associated with an Aegilops umbellulata chromosome segment incorporated into wheat. Nature, 211, 1425-1426.

BiRnstiel, M. L., ChIPCHASE, M., AND sPIERs, J. 1971. The ribosomal RNA cistrons. Progress in Nucleic Acid and Molecular Biology, 11, 351-389.

BROWN, D. D., AND WEBER, C. s. 1968. Gene linkage by RNA-DNA hybridisation. Unique DNA sequences homologous to 4s RNA, 5s RNA and ribosomal RNA. F. Mol. Biol., 34, $661-680$.

BURGI, E., AND HERSHEY, A. D. 1963. Sedimentation rate as a measure of molecular weight of DNA. Biophys. F., 3, 309-321.

DARVEY, N. L., AND GUSTAFSON, J. P. 1975. Identification of rye chromosomes in wheat-rye addition lines and triticale by heterochromatin bands. Crop Sci., 15, 239-243.

DRISCOLL, C. J. 1975. First compendium of wheat-alien chromosome lines. Annual Wheat Newsletter, 21, 16-32.

DRISCOLL, C. J., AND JENSEN, N. F. 1963. A genetic method for detecting intergeneric translocation. Genetics, 48, 459-468.

DRISCOLL, C., AND SEARS, E. R. 1971. Individual addition of the cliromosomes of "Imperial " rye to wheat. Agron. Abst., 6.

DVORAK, J., AND KNOTT, D. R. 1974. Disomic and ditelosomic additions of diploid Agropyron elongatum chromosomes to Triticum aestivum. Can. F. Gen. Cytol., 16, 399-417.

FLAVELL, R. B., AND RIMPAU, J. 1975. Ribosomal RNA genes and supernumerary B chromosomes of rye. Heredity, 35, 127-131.

FLAVELL, R. B., RIMPAU, J., AND SMITH, D. B. 1977. Repeated sequence DNA relationships in four cereal genomes. Chromosoma (Ber1.), 63, 205-222.

FLAVELL, R. B., AND SMITH, D. B. 1974. Variation in nucleolar organiser ribosomal RNA gene multiplicity in wheat and rye. Chromosoma (Berl.), 47, 327-334.

FLAVELL, R. B., AND SMITH, D. B. 1976. Nucleotide sequence organisation in the wheat genome. Heredity, 37, 231-252.

gustafson, J. P., AND BENNETr, M. D. 1976. Preferential selection for wheat-rye substitutions in 42-chromosome Triticale. Crop Science, 16, 688-693.

HART, G. E., MCMILLIN, D. E., AND SEARS, E. R. 1976. Determination of the chromosomal location of a glutamate oxaloacetate transaminase structural gene using Triticum agropyron translocations. Genetics, 83, 49-61.

IRANI, B. N., AND BHATIA, C. R. 1972. Chromosomal location of alcohol dehydrogenase gene(s) in rye using wheat-rye addition lines. Genetica, 43, 195-200.

ISLAM, A. K. M. R., SHEPHERD, K. W., AND SPARROW, D. H. B. 1975. Addition of individual barley chromosomes to wheat. Proc. 3rd Int. Barley Genetics Symp., 260-270.

KNoTT, D. R. 1961. The inheritance of rust resistance. VI. The transfer of stem rust resistance from Agropyron elongatum to common wheat. Canad. F. Plant Sci., 41, 109-123.

KOLLER, O. L., AND ZELLER, F. J. 1976. The homoeologous relationships of rye chromosomes 4R and 7R with wheat chromosomes. Genet. Res., Camb., 28, 177-188.

LURQUiN, P. F. 1977. Integration versus degradation of exogenous DNA in plants: an open question. Progress in Nucleic Acid Research and Molecular Biology, 20, 161-207. 
MACDONALD, T., AND SMTth, н. H. 1972. Variation associated with an Aegilops umbellulata chromosome segment incorporated into wheat. II. Peroxidase and leucine aminopeptidase isozymes. Genetics, 72, 77-86.

MACGREGOR, H. C., AND MIZUNo, s. 1976. In situ hybridisation of nick-translated ${ }^{3} \mathrm{H}$ ribosomal DNA to chromosomes from salamanders. Chromosoma, 54, 15-25.

MANIATIS, T., JEFFREY, A., AND KLEID, D. G. 1975. Nucleotide sequence of the rightward operator of phage $\lambda$. Proc. Nat. Acad. Sci. (Wash.), 72, 1184-1188.

METTIN, D., BLUTHNER, w. D., AND SCHLEGEL, c. 1973. Additional evidence on spontaneous 1B/1R wheat-rye substitutions and translocations. Proc. 4th Wheat Genet. Symp., 179-184. Mo. Agric. Exp. Stn., Columbia, Mo.

MOHAN, J., AND FLAVELL, R. B. 1974. Ribosomal RNA cistron multiplicity and nucleolar organisers in hexaploid wheat. Genetics, 76, 33-44.

PARDUE, M. L., AND GALL, J. G. 1975. Nucleic acid hybridisation to the DNA of cytological preparations. In: Methods in Cell Biol., 10, 1-16.

RILEY, R., AND CHAPMAN, v. 1958 The production and phenotypes of wheat-rye chromosome addition lines, Heredity, 12, 301-305.

RILEY, R., AND CHAPMAN, v. 1960. The meiotic behaviour, fertility and stability of wheatrye chromosome addition lines. Heredity, 14, 89-100.

RILEY, R., CHAPMAN, v., AND JOHNSON, R, 1968. The incorporation of alien disease resistance in wheat by genetic interference with the regulation of meiotic chromosome synapsis. Genet. Res. (Camb.), 12, 199-219.

RILEY, R., AND KIMBER, G. 1966. The transfer of alien genetic variation to wheat. Annual Report of Plant Breeding Institute, Cambridge. 6-36.

RILEY, R., AND MACER, R. C. F. 1966. The chromosomal distribution of the genetic resistance of rye to wheat pathogens. Canad. 7 . of Genetics and Cytol., 4, 640-653.

SARMA, N. P., AND NATARAJAN, A. T. 1973. Identification of heterochromatic regions in the chromosomes of rye. Hereditas, 74, 233-238.

SEARS, E. R. 1956. The transfer of leaf-rust resistance from Aegilops umbellulata to wheat. Brookhaven Symp. Biol., 9, 1-22.

SEARS, E. R. 1972. Chromosome engineering in wheat. Stadler Symposium, 4, 23-38. University of Missouri, Columbia, U.S.A.

SINGH, R. J., AND RöBbELEN, G. 1976. Giemsa banding technique reveals deletions within rye chromosomes in addition lines. Z. Pfanzenzüchtg., 76, 11-18.

SMTTH, D. B., AND FLAVELL, R. B. 1974. The relatedness and evolution of repeated nucleotide sequences in the genomes of some Gramineae species. Biochem. Genet., 12, 243-256.

SMITH, D. B., AND FLAVELL, R. B. 1975. Characterisation of the wheat genome by renaturation kinetics. Chromosoma (Berl.), 50, 223-242.

SMTTH, D. B., AND FLAVELL, R. B. 1977. Nucleotide sequence organisation in the rye genome. Biochim. Biophys. Acta, 474, 82-97.

SMITH, D. B., RIMPAU, J., AND FLAVELL, R. B. 1976. Interspersion of different repeated sequences in the wheat genome revealed by interspecies DNA/DNA hybridisation. Nucleic Acid Res., 3, 2811-2826.

STUDIER, F. w. 1965. Sedimentation studies of the size and shape of DNA. 7. Molec. Biol., $11,373-390$.

TANG, K. s., AND HART, G. E. 1975. Use of isozymes as chromosome markers in wheat-rye addition lines and in triticale. Genet. Res. (Camb.), 26, 187-201.

VERMA, s. C., AND REES, H. 1974. Giemsa staining and the distribution of heterochromatin in rye chromosomes. Heredity, 32, 118-122.

wienhues, A. 1966. Transfer of rust resistance of Agropyron to wheat by addition, substitution and translocation. Proc. 2nd Int. Wheat Genet. Symp. Hereditas Suppl.: Vol. 2, 370-381.

zeller, F. J. 1973. 1B/lR wheat-rye chromosome substitutions and translocations. Proc. 4th Wheat Genet. Symp., 209-221. Mo. Agric. Exp. Stn., Columbia, Mo. 